\title{
Marxist and non-Marxist
}

\section{aspects of the cultural-historical psychology of L. S. Vygotsky*}

\section{Summary}

It was not only Marxism which influenced Vygotsky. He was a child of the Silver Age of Russian culture and philosophy and the influence of this should not be underestimated. Some traits in Vygotsky's theory, traditionally considered as Marxist - such as the concept of the social origins of mind or sign as psychological tool - have deeper and wider roots in works of Shpet, Blonsky, Sorokin and Meierhold. As for Marxism as such, it must be mentioned that during all three periods of his creative evolution Vygotsky had different approaches to what was true Marxist psychology and how it should be built. These are items this paper is focused on.

\section{Introduction}

Marxist philosophy undoubtedly exerted a great influence on various aspects of Vygotsky's ideas. Marxist sources in Vygotsky's cultural-historical psychology constitute a major theme in discussions of Soviet (Atramonov, 1994; Davydov \& Radzikhovskii, 1985), modern Russian (Asmolov, 1998; Leont'ev, 2003;

A debt of gratitude is owed to Mariane Hedegaard who has taken the time to reed and comment on this paper. I would like to thank Professor Pentti Hakkarainen, from Oulu University, Finland for invaluable help and support.
Yaroshevsky, 1992), and Western literature (Elhammoumi, 2001; Jensen, 1999; Lee, 1985; Seve, 1999; Tolman, 2001; Wertsch, 1981, 1983, 1985b;),

Thus, S. Toulmin notes that

it should be evident, that Vygotsky's...quotations from Marxist fathers, and respectful references to Marx and Engels...represent something more than hagiography or political lip service... Vygotsky was more than happy to call himself a Marxist. And in any event, leaving all political issues aside, the general frame provided by 'historical materialist' philosophy gave him the basis he needed for developing an integrated account of the relations between developmental psychology and clinical neurology, cultural anthropology and the psychology of art (Toulmin, 1978, p. 51-57.)

In Western literature this general position was supported in a number of ways (see Cole \& Scribner, 1978; Wertsch, 1981; Wertsch, 1985a, and others).

At the same time, modern literature gives an essentially contradictory picture of Vygotsky and Marxism. Thus, according to F. Newman and L. Holzman, he was a scientific father of Marxist psychology in the Soviet Union (Newman \& Holzman, 1993) while J. Bruner 
claims that his Marxism was "closer to Althusser, Habermas and the Frankfurt School than to the Soviet Marxism of his times or of ours" (Bruner, 1987, p.2).

Thus, when we speak about Vygotsky and Marxism we should ask what kind of Marxism we mean? Is it the Marxism of Marx or the diametrically opposed Marxisms of Althusser and Habermas? Perhaps we mean the Marxisms of Trotsky ${ }^{1}$ or even that of V. Lenin. Most likely we mean the Marxism in the spirit of E. Ilyenkov (Bakhurst, 1991, Jones, 2000; Jones, 2001).

Such a contradictory picture indicates a lack of historical perspective in approaching the cultural-historical theory of Vygotsky. His approach and methods changed their focus from reflexes in the early writings (1917-1924), through social behaviour (1925-1927) to the later works which exemplify a truly culturalhistorical approach (see Tudge, 1999, p. 1117). Any attempt to find a cultural-historical theory amidst the pre-1928 writings of Vygotsky would be futile. Not every thought of Vygotsky could be attributed to his famous theory, and what is more, there are some traits within his theory, which are mistakenly identified as exclusively Marxist. In uncovering the nature of the relation between Marxism and Vygotsky, we must address dramatic and even tragic elements.

Vygotsky's philosophical orientation was wider than Marxism. Indeed, his first insights into the problems of the personality and human consciousness were philosophical rather than psychological. Rather than I. Pavlov or K. Marx it is V. Soloviev, N. Berdiaev, A. Belyi

1 Thus, A. M. Etkind notes that in Pedagogical Psychology "Vygotsky quoted the ideas of Lev Trotsky by pages" and that "in the 1991 edition, edited by V. V. Davydov, the quotation marks are removed from the quotation and the name of Lev Trotsky is left out. The authors of... an American monograph on Vygotsky (van der Veer \& Valsiner, 1991), trusting Davydov, quoted this text after its publication as the creation of Vygotsky himself". (Etkind, 1994, p. 29-30.) and the Russian symbolists, A. Potebnya, W. Humboldt, W. Shakespeare, O. Mandelshtam, V. Shklovsky, Yu. Aikhenvald, G. Shpet, P. Blonsky and many others who form his social and cultural environment and act as participants in his scientific dialogues.

Given such a background it is worth examining how Vygotsky himself explained the relationship between his psychology and Marxism. What were his thoughts on Marxist psychology? What were his views on these relations and how did these views change? Is it possible to find in Vygotsky's original texts a sort of "formula" expressing his view on what was Marxist psychology? In other words, discovering the problem of Vygotsky and Marxism, it obviously makes sense to take into account his own opinion on that matter. At the same time the influence of the 'Silver Age' of Russian culture ${ }^{2}$ on Vygotsky is also of interest. It is on these issues which the present paper concentrates.

Vygosky's creative evolution may be divided into three periods. Each of these was characterised by Vygotsky's developing approach to what is (and what is not) Marxist psychology. In contrast to the widespread discussions in the literature of the 'classical' Moscow period when the cultural-historical approach appeared (1928-1934), the earlier stages in the development of Vygotsky's theoretical views are generally presented as being of no serious significance. It thus makes sense to begin with this 'pre-classical' period.

2 "The Silver Age of Russian culture" is a well known period of Renaissance of arts and culture in the Russian Empire at the beginning of the 20.th century, tragically interrupted by the Bolsheviks in 1917. Vygotsky-the student was one of the most active participants of that cultural space. His first published articles were on literary criticism and theatre (for more details see Van der Veer \& Valsiner, 1991; Vygodskaya \& Lifanova, 1996). 


\section{From reflex to social behaviour: materialistic psychology (1917-1924)}

At least three works, namely, Pedagogical Psychology, Psychology of Art (written between 1917 and 1924) and Methods of Reflexological and Psychological Investigation (1926) are of importance for that period of Vygotsky's theoretical evolution.

The first two of these represent the reflexological approach to the human mind. "The theory of...reflexes is the basis upon which a new psychology must be built." (Vygotsky, 1926b, p.7) ${ }^{3}$. The concept of reflex (a modification of I. Pavlov's ideas which includes 'speech reflex') was the basic explanatory principle. The human mind and consciousness (thoughts and emotions) were viewed as a system of inhibited speech reflexes. In brief, Vygotsky approached reflexology (Pavlov's and Behterev's) as materialist (Marxist) psychology. Thus, human consciousness becomes nothing more than the specific "reflex of reflexes" (Vygotsky, 1926b, p.45).

The third important work of that period was his famous report, Methods of Reflexological Research Applied to the Study of the Psyche, presented at the Second All-Russian Congress on Psychoneurology in Petrograd in January 1924. It was published in 1926 as an article entitled 'Methods of Reflexological and Psychological Investigation' in the journal Problems of Contemporary Psychology, edited by K. N. Kornilov (Vygotsky, 1926a, Vygotsky, 1994). Following this presentation, Vygotsky was invited by K. N. Kornilov, Director of the Moscow Psychological Institute, to work in Moscow.

A. A. Leont'ev gives the reason for this important event in Vygotsky's life in terms of his Marxist orientation which attracted the

3 In this paper all translations from Russian sources are mine - Nikolai Veresov attention of K. N. Kornilov. In accordance with the official task of the young members of staff of the Moscow Psychological Institute (Leont'ev, A., 1996, p. 7), Kornilov sought to develop Marxist psychology. In order to clarify the background to these events it is worthwhile considering the state of Soviet psychology at that time.

Those years were characterised by strenuous debates and arguments concerning such problems as the relationship between subjective and objective methods of analysis, or between introspection and 'extraspection'. One such argument pitted reflexology against psychology. Debates concentrated around such issues as reductionism, antireductionism and the systemic analysis of mental phenomena. In his report, Vygotsky formulated his own theoretical position with respect to those arguments. We may be sure that the appearance at the Petrograd Congress rostrum of an obscure provincial teacher was received, despite his striking and original report, as yet another attempt to support the position of K. Kornilov and his followers in the struggle between the reflexologists and the psychologists.

The purpose of the report was to combine reflexology (the objective scientific method of analysis) with psychology (the science of the subjective internal world of the individual) to form a single science - the objective psychology of consciousness. Vygotsky even described himself as "more of a reflexologist than Pavlov" (Vygotsky, 1926a, p. 42).

In his report, Vygotsky did not touch on Marxism as such, but his acute criticism on the one hand of empirical subjective psychology and on the other of reflexology impressed the representatives of the new psychological party, which was searching for objective methods of studying consciousness. We could even say that it was not the Marxism in Vygotsky's report and theoretical position which attracted the attention of Kornilov's group; what was really original in Vygotsky's views at that time 
might be encapsulated by the words monism and materialism. In considering the possibilities of creating a monistic materialistic theory of consciousness on the basis of reflexology (i.e. 'materialistic psychology') Vygotsky compared classical methods of reflexological analysis with classical methods of psychological analysis and contrived to unify these two sciences into one based on methods of objective materialistic methods (Vygotsky, 1982, p. 60-62).

Summarising our brief overview of $\mathrm{Vy}$ gotsky's position during this first period, we note that the formula of consciousness as a "reflex of reflexes" is quite far removed from the main ideas of cultural-historical theory. As for Marxism in psychology, Vygotsky was not the only Russian psychologist who considered reflexology as a materialist (Marxist) psychology, since it was the only basis for creating a monistic materialistic theory of human consciousness. It should be mentioned, on the other hand, that very soon he became disappointed with this "formula" since, on his opinion, the concept of reflex could not become the fundamental concept of psychology as a concrete science of human behaviour. The contradiction between the objective methods of analysis of human mind Vygotsky was searching for, and the reflex as basic concept, was the moving force forwarding Vygotsky's thought to the second period of development of his theoretical views.

\section{From social behaviourism to psychological materialism (1925-1927)}

There are two works of Vygotsky reflecting this new stage of his thoughts during the second period from 1925 to 1927 . They are Consciousness as a Problem in the Psychology of Behaviour (1925) and A Historical Sense of Psychological Crisis (1927).
As a result of various adverse technical and organisational circumstances, Consciousness as a Problem in the Psychology of Behaviour appeared in 1925 before the written version of the Petrograd report (Vygotsky, 1925; Vygotsky, 1979; Vygotsky, 1982, p.78-98; Vygotsky, 1999).

According to V. Davydov and L. Radzikhovskii, Vygotsky "formulated three programmes" in that article for the study of consciousness. These were (1) consciousness is a reflex of reflexes, (2) consciousness is a question of the structure of behaviour, and (3) consciousness is a feature of human labour activity (Davydov \& Radzikhovskii, 1985, p. 45-48). Moreover, “in Vygotsky's third programme...consciousness emerged as an aspect of the structure of labour activity" and this programme (in contrast to the first two) was of decisive significance "relying directly on Marx's ideas" (Davydov \& Radzikhovskii, 1985, p. 48).

Let us again take a look at the text. There are two places in the article where Vygotsky borrowed directly from Marxism. Firstly, in speaking about Marx's famous illustrations of the spider and the architect, Vygotsky noted that "Marx's explanation, which is beyond dispute, means nothing more than a doubling of experience that is compulsory for human labour" (Vygotsky, 1925, p. 183).

Secondly, when discussing the point of instinctive behaviour in animals, Vygotsky wrote, "The spider that weaves his web and the bee that builds his cell out of wax do this out of instinct, mechanically, always in the same way, and in doing so they never display any more activity than in any other adaptive reactions." (Vygotsky, 1982, p. 84) ${ }^{4}$ This for Vygotsky was no more than a simple illustration of the process of 'active adaptation' in humans, which has of

4 In the English translation of the article "adaptive reactions" was translated as "adaptive activities". (Vygotsky, 1979, p.68). 
course nothing in common with "consciousness as a feature of human labour activity".

What are the main features of Vygotsky's programme of studying consciousness? Let us briefly examine the article:

1. In contrast to his own previous views $\mathrm{Vy}$ gotsky sharply criticised even the very possibility of any reflexological explanation of consciousness.

"A reflex is an abstract concept; methodologically it is extremely valuable, but it cannot become the fundamental concept of psychology as a concrete science of human behaviour... We should beware of any direct transportation of reflexological laws into psychology...We ought to study not reflexes, but behaviour, its mechanism, its component parts, and its structure. Actually, what we are studying in every case is behaviour, since we invariably organise beforehand, in some way or other, the behaviour of the subject in order to ensure that this or that reaction or reflex will dominate; otherwise, we would achieve nothing." (Vygotsky, 1925, pp. 179 -181).

2. Therefore,

“...the problem of consciousness must be solved in psychology in a sense that consciousness is an interaction, reflection, and mutual excitation of different systems of reflexes. What is conscious is what is transmitted as an irritant to other systems in which it has a response. Consciousness is always an echo, a response apparatus." (Vygotsky, 1925, p. 187.)

3. "The individual aspect of consciousness is constructed as derived and secondary, based on the social and exactly according to its model." (Vygotsky, 1925, p. 196) Moreover, citing here Paul Natorp (but not K. Marx), Vygotsky adds, "This is very close to the division of the individual person into an 'Ego' and an 'Id', which S. Freud analytically describes. (Vygotsky, 1925, p. 196) Furthermore, Vygotsky saw the connection between the individual consciousness and the social mechanisms of communications within the framework of social behaviour in terms of reversible reflex. "It is extremely important here to establish, if only in passing, that... the mechanism of social behaviour and the mechanism of consciousness are the same. Speech...is a system of... reflexes of consciousness, a system for reflecting other systems." (Vygotsky, 1925, p. 195.)

One can see that Vygotsky's approach is very close to that of the social behaviourists: consciousness is a relation between social reactions according to social models.

Thus, not three but only one scientific programme of studying consciousness was presented. Moreover, there appear to be insufficient grounds for speaking of a "programme of studying the consciousness as a feature of human labour activity" relying directly on Marx's ideas'.

Historical Sense of Psychological Crisis (1927) or as it is known in the West, Historical Sense of Crisis in Psychology is of great relevance to the topic under discussion. This book marks a watershed between early Vygosky and the Vygotsky by the cultural-historical theory. In this work (which remained unpublished until 1982) we could find a set of direct considerations by Vygotsky about Marxist psychology. Here is the place from the book, which is quoted almost everywhere when the problem of Vygotsky's theory and Marxism is discussed.

"I do not want to discover what psyche is by cutting out a pair of quotations. I want to learn from the whole of Marx's method how to build the science, how to approach the investigation of the psyche." (Vygotsky, 1982, p. 421.)

5 I can only explain this in such a way that Davydov and Radzikhovskii have access to an unknown version of Vygotsky's article, which differs from both Russian editions as well as from the English ones. 
It seems that clear understanding of this formula is possible only in the wider context of Vygotsky's considerations, presented in the text. Let us try to restore that context in brief.

He recalls how he had once been struck by a question asked by a certain Western scientist. The question was "What psychology do you study in Russia? Your being Marxists does not explain yet what sort of psychologists you are. Knowing the popularity of Freud in Russia, I first thought of the Adlerians; they are also Marxists, but you have quite a different psychology, haven't you? We are Social Democrats and Marxists too, but we are also Darwinists and Copernicans." (Vygotsky, 1982, p. 434.)

That conversation gave Vygotsky food for thought and for arguments against the term 'Marxist psychology'.

- Firstly, just as the theory of Darwin forms a part of biology and that of Copernicus a part of astronomy, there must be a concrete theory to determine the inner structure of psychology. "A Marxist historian would never refer to 'a Marxist history of Russia'. He would assume that the thing was clear of itself since it is synonymous with 'true or scientific'.” (Vygotsky, 1982, p. 434.) Thus, to merely state that scientists in the Soviet Union studied Marxist psychology would be to evade the issue.

- Secondly, Vygotsky had another argument against the term 'Marxist psychology': "Marxist psychology is not a school among schools but the only true psychology as a science. There can be no other psychology but this one". (Vygotsky, 1982, p. 435.)

For Vygotsky the term 'Marxist psychology' "coincided with that of scientific psychology in general wherever and by whomsoever it might be developed" (Vygotsky, 1982, p. 435).
This might be the formula, probably the key formula, expressing Vygotsky's understanding of what is Marxist psychology.

Vygotsky rejected the way of building Marxist psychology by taking certain formulae of dialectical laws from philosophy and explaining psychological processes and their laws in terms of concrete manifestations of the universal laws of dialectic. On this point he criticised K. Kornilov who was one of the scientific leaders of Marxist psychology in 1920s.

Firstly, Kornilov's approach to the creation of Marxist psychology "in the light of dialectical materialism" was quite typical for that time. To understand the nature of consciousness was to explain it in accordance with materialism and dialectic. The main idea was to explain the 'dialectical' nature of psychical processes and laws by presenting them as examples of fundamental and universal philosophical laws such as the law of the mutual penetration of opposites, the law of the transformation of quantity into quality and the law of the negation of negation. In particular, the changes in perception of figures described in Gestalt theory were explained in accordance with the law of transformation of quantity into quality (Kornilov, 1930, p. 255).

So,
"immediate application of the theory of dialectical materialism to the problems of natural science, in particular to biology and psychology, is impossible as it is impossible to apply it immediately to history or sociology. Like history, sociology requires the special mediating theory of historical materialism, which explains the particular significance of the abstract laws of dialectical materialism for a par- ticular group of phenomena. Similarly, a theory of biological materialism, or psychological material- ism, as a mediating science explicating the concrete application of the abstract tenets of dialectical ma- terialism to a particular domain of phenomena, is indispensable." (Vygotsky, 1982, p. 419-420.) 
The problem of Marxism and psychology, Vygotsky argued, is much more complex than the mere construction of psychology in accordance with Marxism. Psychology needs a certain methodology-theory (meta-theory) of its own but not one taken strictly from philosophy. For political economy, history and sociology such a mediated meta-theory (historical materialism) was devised by K. Marx in Capital.

In this sense psychology needs its own Capital. In this (and only in this particular but principal) context Vygotsky argues: "In order to create such enabling theories - methodologies in general sciences - it is necessary to discover the essence of the given area of phenomena, the laws of their changes, their qualitative and quantitative characteristics, their causality; to create the categories and concepts relevant to them - in other words, to create one's own Capital." (Vygotsky, 1982, p. 420.)

According to Vygotsky, the idea is not to impose the dialectical principles on nature but to find them there. Similarly, as Capital was not the application of dialectical materialism to the problems of political economy and society, the future Capital in psychology was seen only as the possibility of expressing and describing its own objects and their laws but not as the application of dialectical materialism. Consequently, the categories, concepts and laws in this Capital must be psychological but not philosophical ones (Vygotsky, 1982, p. 420).

The conclusion of the work comes across rather like a verdict:

\footnotetext{
"Ultimately, there is no Marxist psychology as yet. This must be seen as a historical task, not as something given. But in the present state of affairs it is difficult to avoid the impression that there is a considerable lack of scientific seriousness and responsibility surrounding this appellation." (Vygotsky, 1982, p. 433)
}

Bearing this in mind let us now turn to the final period of Vygotsky's work (1927-1934) and his famous cultural-historical theory.

\section{Cultural-historical theory (1927-1934): true Marxist psychology?}

A survey of the literature on the subject demonstrates quite clearly that at least three ideas from the cultural-historical theory may be viewed as Marxist. These are (1) the role of human activity (practice) in mental development, (2) social origins of mind and (3) cultural signs/symbols as 'psychological tools'. But do we have enough evidence for the assertion that these ideas are exclusively Marxist? Before coming to this point let us change the angle of analysis.

\section{General genetic law of development - Marxist roots?}

As classical physics is based on Newtonian laws, the theory of Vygotsky is based on a law, called "the general genetic law of cultural development". It seems to be clear that if we do not understand (or just misunderstand) the general law, we could hardly understand the whole theory based on this law. We can assume that clear understanding of the general law might bring a new light how culturalhistorical theory is connected with Marxist philosophy. Is the general law connected with a Marxist approach, or maybe there are some other roots of it?

Here is the formulation of the general genetic law of cultural development as it was presented in Vygotsky's original text

\footnotetext{
“... any function in the child's cultural development appears on stage twice, that is, on two planes. It firstly appears on the social plane and then on a psychological plane. Firstly among people as an inter-psychological category and then within the child as an intra-psychological category. This is equally true with regard to voluntary attention, logical memory, the formation of concepts and the development of volition." (Vygotsky, 1983, p.145.)
} 
It is curious that in the literature, which Western readers work with, there is a slightly different formulation.

This comes from the Mind in Society of 1978.

“...every function in the child's...development appears twice: first, on the social level, and later, on the individual level; first between people (interpsychological), and then inside the child (intrapsychological)... (Vygotsky, 1978, p. 57)

This formulation was quoted and repeated so many times that it gradually obtained the status of a classical formulation for generations of researchers.

The other interpretation belongs to Vasilii Davydov.

Every function "appears...twice, firstly as collective, social activity (kollektivnaya, sotsial'naya deyatelnost) and then as individual activity (deyatelnost individualnaya)" (Davydov, 1996, p. 24)

At a first glance, despite slight differences these two interpretations look more or less similar and correspond to Vygotsky's formulation. They both emphasise the most important aspect - the social origins of mind, as fundamental in Vygotsky's approach to human development. Even more, giving such an interpretation, V. Davydov directly says that here is the central point that connects Vygotsky's approach to the Marxist tradition (Davydov, 1996, p. 24). We will come to the term "activity" in Vygotsky's theory later, but now let us ask whether another interpretation of the general genetic law is possible?

To find the answer, to understand Vygotsky's formulation of the law, to identify its every word, it is needed to know the language the formulation was written in.

Let us try to make a step to such kind of identification.

According to Vygotsky, every function appears firstly on the social plane, among people.
But the crucial point is that the function DOES NOT and cannot appear IN the social relations.

"...every higher mental function, before becoming
internal mental function, previously was a social
relation between two people". "All mental func-
tions are internalized social relations" (Vygotsky,
1983, p.145 -146).

So, before becoming individual function, it was not in a social relation, it was a social relation itself. Social relation is not the "area", not the field, and not the "level" where mental function appears, - the social relation itself becomes child's individual function - herein lies the answer.

If every higher mental function was a social relation between two people, does it mean that every social relation can become a mental function? Definitely not! Nevertheless, in Vygotsky's formulation we can find a clear notion of what type or relation can become a mental function. The point is that to understand it we have to turn to the language of Russian culture of the beginning of the 20.th century. We have to recall that Vygotsky came to psychology from the area of humanities and culture. He belongs to the generation of "The Silver Age of Russian culture". Theatre, poetry, arts, literature of that period had a language of their own which was almost totally lost after the Revolution.

In our context I mean particularly the word "category" Vygotsky uses in the formulation. What does the word "category" actually mean? From the times of Aristotle, especially in German classical philosophy, the category is the most abstract, the most general concept (Spirit and Matter are examples of categories). It sounds strange therefore that the mental function appears twice, first as inter-psychological category, and then as intra-psychological category. Maybe it is just a sort of metaphor, which can be easily omitted in translation?

Not at all! On the contrary, the word "cat- 
egory" (which is repeated twice in the formulation of the general law) has definite meaning. In Russian pre-revolutionary theatre's vocabulary, the word category meant "dramatic event, collision of characters on the stage". Vsevolod Meierhold (famous Russian theatre director) wrote that category is the event, which creates the whole drama (Meierhold, 1920). Sergey Eisenstein, the famous film director wrote: "Category is a unit of drama". Vygotsky was familiar with the language of Russian theatre and arts and had to use the word "category" to emphasize the character of the social relation, which was to become the individual function. The social relation he means is not an ordinary social relation between two individuals. This is a social relation that appears as a category, i. e. as emotionally coloured and experiencing collision, a contradiction between two people, the dramatical event, a drama between two individuals. Being emotionally and mentally experienced as social drama (on the social plane) it later becomes an individual intrapsychological category.

Probably the best (and familiar to everybody) example here might be the case of debate between the two people. Imagine (or just remember) that one day you met a friend and had a debate, expressing opposite positions. Dramatical collision in a debate, experienced by the both participants, can lead to a sort of self-reflection. In the course of time, (for example next morning) one of the participants remembers the event and what he has done and said. It could happen like «I was wrong saying that, I made a mistake...I should not say such sharp words...I was so aggressive and did not pay enough attention to what he tried to say...How stupid I was yesterday..."

We see here that the individual now experiences the same category, intra-psychologically. In this type of internal category, all the mental functions of the individual are involved (memory - "I said something rough", emotions - "How stupid my behaviour was, what a shame", thinking - "I have to think it over and never repeat such bad things", volition - "I must stop it, I will never forget what I have done. I promise myself to be patient..."

Such emotionally experienced collision brings radical changes to the individual's mind, and therefore it is a sort of act of development of mental functions - the individual becomes different, he becomes higher and above his own behaviour. Without internal drama, an internal category, such kind of mental changes are hardly possible ${ }^{6}$.

This consideration about the dramatical character of development, reflected in the word "category", brings the following question: are there any other words and terms in Vygotsky's formulation, which are also of primary importance?

It seems that words "on the stage" and "on two planes" are not metaphors, which might be omitted or ignored. Scientific formula of the general law of the theory is not a good place for any kind of metaphors. Stage in Russian means "scene", the arena, literally the place in the theatre where actors play. Scene has two planes - the front plane (also called "the first plane") and the back plane (often called "the second plane" to theatre's traditions, main events of a performance should happen on the front plane of the scene (the same law we could find in visual arts). So, it means that on the stage of our development, the category appears twice - inter-psychologically (on the first, front plane) and then intra-psychologically (on the second internal individual plane). Therefore, there are no two levels in development, but

6 In another place of the same text, Vygotsky uses the word "drama" directly. "From here comes, that one of the central principles of our work is the experimental unfolding of higher mental process into the drama which happened between the people" (Vygotsky, 1983, p.145)

7 I could compare this with "the role of second plane" in contemporary cinema. 
there are two planes on ONE stage, two dimensions of one event.

All this gives some grounds to assert that discovering the cultural-philosophical roots of cultural-historical theory, we should keep in mind that they were not limited to Marxism the language of Russian cultural-philosophical tradition was the language Vygotsky perfectly spoke. This link with Russian philosophy, culture and arts should not be underestimated.

With this in mind, let us turn to the abovementioned ideas from the cultural-historical theory often seen as Marxist: (1) the role of human activity (practice) in mental development, (2) social origins of mind and (3) cultural signs/symbols as 'psychological tools'.

\section{Human activity and development}

The prevailing opinion in modern literature is that Vygotsky's assertion of the role of human activity was in some sense similar to Marx's well-known First Thesis on Feuerbach. A. N. Leont'ev noted:

"The importance of this category [the category of activity] hardly needs to be emphasised. We need only recall Marx's famous thesis on Feuerbach, in which he said that the chief defect of earlier metaphysical materialism was that it viewed sensuousness only as a form of contemplation, not as human activity or practice...." (Leont'ev, 1981, p. 41.)

This is closely connected with the long tradition of presenting the relations between the two theories, i.e. the cultural-historical and the psychological theories of activity. Soviet representatives of this approach look at these theories as two historical and theoretical stages in the development of Marxist psychology (see, for example, Davydov \& Radzikhovskii, 1985; Davydov \& Zinchenko, 1989). The main point of the discussion is the role and status of the concept of 'activity' in Vygotsky's theory and the theory of activity (for more details see Jensen, 1999; Tolman, 2001; Lektorsky, 1999; Tulviste, 1999).

\section{What does 'activity' mean?}

The English term activity has two Russian equivalents. The first is aktivnost and the second deyatelnost. Aktivnost traditionally refers to processes in the organism or to an active state (in contrast to a passive one). In German aktivnost is rendered by Aktivitat. Deyatelnost is a term referring to the practical, socially organised, object-related, goal-directed activity of an individual (for example, labour activity is trudovaya deyatelnost). In German deyatelnost is Tätigkeit.

Moreover (and this complicates the situation), very often deyatelnost is used in a sense of aktivnost (for example 'brain activity' is 'deyatelnost mozga', or 'higher nervous activity' is 'visshaya nervnaya deyatelnost'). In such cases deyatelnost has nothing to do with Tätigkeit.

Very often, however, and especially in translations of Vygotsky, these two terms are translated into English by the same word, $a c$ tivity, in spite of differences of meaning intended. This leads to numerous mistakes and misunderstandings, particularly amongst those who work with English translations of Vygotsky's works.

According to the theory of A. N. Leont'ev the term deyatel'nost as the central category (Leont'ev, 1974-1975, 1978, 1981) has an absolutely definite and concrete meaning. For example, he wrote, "It is our position that the proper way for psychology...is to introduce the category of object-type activity (gegenständliche Tätigkeit)...We are speaking here about activity, not about behaviour or the processes of nervous physiology..." (Leont'ev, 1974-1975, p. 9.) According to Leont'ev, the term Tätigkeit (deyatel'nost) should be used in contrast to Aktivität (Leont'ev, 1974-1975, p. 6; Leont'ev, 1977, p. 75). 
As for Vygotsky, our analysis shows ${ }^{8}$ that in all of his texts between 1924 and 1927 the term deyatelnost was used not in the sense of Tätigkeit but in that of Aktivität, in line with typical and traditional usage in the physiology and psychology of the time. Vygotsky used this term in the same sense as Ivan Pavlov (higher neural activity - vysshaya nervnaya deyatelnost), Vladimir Bekhterev (correlative activity) and Charles Sherrington (the activity of nervous centres). In any case I could not find in the early texts of Vygotsky the term 'activity' used in the sense of Tätigkeit. This means that the widely held view that the origins of this concept may be found in the early writings of Vygotsky (Kozulin, 1996; Nardi, 1996) can no longer be considered beyond dispute.

As for the writings after $1927^{\circ}$ the situation looks different. Developing his cultural-historical theory, Vygotsky wrote in some cases about activity in the sense of Tätigkeit. Summarising the analysis of the texts, we may formulate three main contexts for the use of this term by Vygotsky:

1. In the article 'Play and its role in the mental development of the child' (Vygotsky, $1966 / 1933$ ) he states that play is a leading activity in early childhood. Later on in the mid 1930s this notion was developed and transformed by A.N. Leont'ev and his collaborators into the concept of leading activity. As for Vygotsky, he did not for-

8 Me made this analysis on the basis of Vygotsky's complete bibliography made by T. Lifanova (Vygodskaya \& Lifanova, 1996, p. 390-418)

9 We focused our text analysis on the Lifanova's list with special emphasis to "The problem of the Cultural Development of the Child" (1928), "The History of the Development of the Higher mental functions" (1983), "The Development of Higher Psychological Functions" (1960, 1977, 1981), "The Instrumental Method in Psychology" (1981), “Concrete Human Psychology” (1989), “Tool and the Sign in a Child's Development (1960), and, of course, in his Magnus Opus "Thinking and Speech" (1934, 1962, 1986). mulate this as a concept, but undoubtedly established preconditions for it.

In contrast, there are numerous places in his works where speech and communication are presented as formative sources of the human mind.

Vygotsky claimed that “...speech plays an essential role in the organisation of higher mental functions." (Vygotsky, 1978, p.23). Later he improved the position, saying that "speech, being initially the means of communication, the means of association, the means of organization of group behaviour, later becomes the basic means of thinking and of all higher mental functions, the basic means of personality formation..." (Vygotsky, 1998, p. 169). As we can see this position is directly connected with the formulation of the "general genetic law of cultural development" discussed above.

2. There is also another place where Vygotsky speaks about the role of activity in the development of human mental functions. In the article of 1930 he discussed the particular problem of the role of labour activity in the process of the child's intellectual development, that is, the development of intelligence (Vygotsky, 1930; Vygotsky, 1976). Even the most careful reader of this article will find nothing about "activity as the substance of human consciousness". On the contrary there are a number of places where Vygotsky emphasises that despite the connection between labour activity and the development of intelligence (umstvennoe razvitie), consciousness is not reducible to it. Labour activity was seen as just one factor of development rather than the source.

It seems, therefore, that we do not have sufficient grounds for the assertion that the concept of activity (deyatelnost, Tätigkeit) played an essential role in his cultural-historical theory. 
It should be also added that by the end of the 1930s, Vygotsky's theory was under attack from A.N. Leont'ev and his Kharkov group because of its lack of recognition of activity as the substance of the human mind, i.e. its non-Marxist character. For example, in the article of 1939 P. I. Zinchenko, closest associate of Leont'ev, drew a sharp contrast between the "idealistic non-Marxist communicationbased conception of Vygotsky" and the "materialistic Marxist activity-based conception of Leont'ev" (Zinchenko, 1939/1983-1984). In particular, he claimed that

\begin{abstract}
"Vygotsky's fundamental error is..[that] he misconstrued the Marxist conception of the historical and social determination of the human mind. Vygotsky understood the Marxist perspective idealistically... The source of mental development was thought to be communication of the subject's mind with the cultural, ideal reality rather than his actual relationship to reality." (Zinchenko, 1983-1984, p. 66)
\end{abstract}

\section{Moreover, Vygotsky’s mistake}

\begin{abstract}
"impeded any understanding of the true, concrete, psychological source of the origin and development of...mental activity...This led Vygotsky to the idea of communication as the source and prime mover of the development of the child's consciousness, to an idealistic understanding of communication in terms of 'spiritual intercourse', as speech communication rather than as the mutual relations of people with one another, relations that include their 'material intercourse' (Marx)." (Zinchenko, 19831984, p. 71)
\end{abstract}

This does not mean that P.I. Zinchenko misunderstood Vygotsky's approach. Rather it indicates that in 1930s nobody suspected, that cultural-historical theory might have anything to do with the concept of activity as the source of the development of the human mind.

\section{Social origins of mind}

Undoubtedly the social origin of mind is one of the distinguishing features of Vygotsky's approach. It was first formulated in his early writings as follows: "Our personality is organised according to the same model as social communication." (Vygotsky, 1926a, p. 178).

As for the writings of 1927-1934, in its full form this idea was presented in the beginning of the 1930s in Development of Higher Psychological Functions (Vygotsky, 1960, p. 13-223, Vygotsky, 1981); “everything internal in higher forms was external... When we speak of a process, 'external' means 'social'. Any higher mental function was external because it was social." (Vygotsky, 1981, p. 162.) What was really new in Vygotsky's formulation was that the social world was seen not as a factor of development but as the source of the human mind.

This formulation coincides with the famous thesis by Marx: "It is not the consciousness of men that determines their existence but, on the contrary, their social existence that determines their consciousness." (Marx, 1859)

But does this mean that it must be identified as a Marxist trait in Vygotsky's theory? Did Vygotsky himself considered his formula to occupy the Marxist position? There is some evidence for that. Thus, he wrote:

\footnotetext{
"To paraphrase a well-known position of Marx's, we could say that the psychological nature of humans represents the aggregate of internalised social relations that have become functions for the individual and forms of his/her structure... All higher mental functions are internalised social relationships... We do not want to say that this is the meaning of Marx's position but we see in this position the fullest expression of that toward which the history of cultural development leads us...." (Vygotsky, 1981, p. 164-165).
}

It should be pointed out that the idea of the social origins of mind is not originally Marxist. In particular, Wilhelm Wundt propounded the notion that higher psychological processes could only be investigated through a historical study of cultural products such as tales, language and cultural customs. G. H. Mead, J. Dewey, E. Durkheim, E. Cassirer and many 
others proceeded from the assumption that the nature of human consciousness is determined by sociocultural factors (see, for instance, Cole, 1995, p. 5; Maffiolo, 1993; NetchineGrynberg, 1995). In any case, to paraphrase Marx's Sixth Thesis on Feuerbach does not mean to construct 'Marxist psychology'.

Moreover, if we take a look at this position from the perspective of a "general genetic law of development", we could find some grounds for the assertion that the idea of the social origins of the mind had deeper (even hidden) roots in the philosophy of "The Silver Age of Russian culture".

We have biographical data to confirm that during his university years (1913-1916) Vygotsky attended lectures by G. G. Shpet (1879-1937) and participated in his seminars on 'ethnic psychology'. It is remarkable that the question of the influence of the ideas of Gustav Shpet or on a wider scale of Russian idealist philosophy on Vygotsky was not debated in Soviet literature. Resent Russian sources on this theme are presented by works of Martsinkovskaya (Martsinkovskaya, 1999) and Zinchenko (Zinchenko, 2003). I could add to this at least two important points.

For political and ideological reasons, Vygotsky was not able to even mention the name of Shpet, but he definitely was acquainted with his concept. Firstly, in his 'ethnic' psychology G. Shpet defended the notion of objective meaning, independent of the individual, and of ideas realised in history. However, he pointed out that the psychological aspect is made patent precisely in the act of their being realised by empirical subjects. He presented the idea of combining the individual senses and social meanings into a single structure. "A cultural phenomenon such as the expression of sense is objective but in it, within this expression, there is also a conscious... attitude toward this 'sense' and it is this attitude that is the subject matter of psychology. Not sense, not meaning, but co-meaning accompanying the realisation of the historical, the subjective responses and experiences, and attitude toward it, are the subject matter of psychology." (Shpet, 1989, p. 11). Let us compare this now with the Vygotskian thesis:

"Initial forms of affective-semantic formations (affektivno-smislovie obrazovaniya) of human consciousness exist objectively outside of the separate person, they exist in human society as products of arts.... i.e. these forms exist earlier than individual or subjective affective-semantic formations." (Vygotsky, 1991, p.211)

Later Vygotsky proposed that meaning be regarded as a structural component of the unit of analysis of the mind. Furthermore, Vygotsky considered that the nature of meaning is social, that meaning is really co-meaning, that is, generalised social relations within the culture.

Secondly, in his psychological theory Shpet defined two types of environment the natural and the spiritual. "There are two directions in which the experiences of the single consciousness move through its own causality - the natural environment and the spiritual one." (Shpet, 1989, p. 508) According to Shpet, neither materialistic no intellectualistic psychology is able to describe the nature of relations and the attitude of individual consciousness and the spiritual environment (Ibid.). This idea is remarkable from the methodological point of view since the notion of psychological dualism and the limitations of one-sided approaches in psychology were much criticised by Vygotsky in his Methods of Reflexological and Psychological Investigation (1926) and later in Historical Sense of Psychological Crisis.

We may add than the cultural-historical theory of the development of higher mental functions worked out by Vygotsky in 19271928 was an attempt to overcome the traditional dualism in the psychological explanation of the mind. Instead, it chose as its basis monistic explanations of the relations between the 
man and his cultural environment. It is worth remembering that Vygotsky used the idea of cultural environment and also the concept of two types of development as one of the basic foundations of his theory of human consciousness. Of course, the influence of Shpet was not a direct or strict one. However, it demonstrates that Vygotsky was not a 'lone thinker'. He was a child of the intellectual and cultural environment of his time which included more than just the philosophy of Marxism and naturalistic psychology.

\section{Sign mediation and 'psychological tools'}

Tools of labour, psychological tools and symbolic mediation are widely discussed as Marxist themes in Vygotsky's approach (see, for example, extended discussions on this in Jones, 2000, and Zinchenko, 1995).

For the purposes of the present article it makes sense to formulate this conception in the following terms.

Firstly, higher mental functions are mediated by cultural tools. Accordingly, “...the central fact of our psychology is that of mediation." (Vygotsky, 1982, 166)

Secondly, according to Vygotsky this type of organisation is basic to all higher mental functions. The use of signs leads humans to a completely new and specific structure of behaviour, breaking away from the traditions of biological development and creating a new form of a culturally based mental functions (Vygotsky, 1978, p. 40.).

Finally, discussing the problem in The Development of Higher Psychological Functions, written in the late 1920s, Vygotsky claims that the sign acts as an instrument of psychological activity (aktivnost in the original Russian text - N. V.), "...in a manner analogous to the role of a tool in labour." (Vygotsky, 1977, p. 69) This seems to be very close to the Marxist idea of the role of tools of labour in the development of human beings.

But the point to emphasise is that the whole picture is deeper and more complicated and requires more careful analysis.

\section{Signs, tools of labour and mediation}

Claiming that the use of cultural signs is analogous to the use of tools, Vygotsky stresses that in spite of the similarity between and common features shared by these two forms of activity, there are some essential differences (Vygotsky, 1977, p. 69).

"The most fundamental difference between sign and tool is the manner of their orientation. The function of the tool is to serve as a conductor of human influence on the object of activity (deyatelnost-N.V.). It is externally oriented; it must exert an effect on its object. It is a means of performing external activity (deyatelnost) aimed at mastery over nature. By contrast, the sign changes nothing in the object of the psychological operation. It is a means of exerting psychological influence on behaviour, be it one's own behaviour or that of another. It is a means of performing internal activity directed at mastery over oneself; the sign is internally directed..."(Vygotsky, 1982,Vol.3, p.90).

Developing this point in Tool and Sign prepared in 1930 (and mistakenly translated as 'Tool and Symbol' - see Vygotsky, 1978, p.ix), he mentions that the sign is, firstly, a means towards social contact, a way of exerting influence on others. Only later does it appear as a means of influencing oneself ( $\mathrm{Vy}$ gotsky, 1982,Vol.3, p.144).

In other words, for Vygotsky the sign is not like tool of labour (just as an analogue is not a synonym!). A cultural sign (for example, a word, gesture or even a traffic sign) makes sense in its being directed towards other people. A sign is a means for conducting social relations (in the form of communication), including the wide social context of communication. The concrete social relations within which the child participates in communication are the source of the human mind (including volitional-emotional components). In other 
words, sign as a psychological tool originates in the social situation of development. Moreover, internal activity (sign-mediated mental functions, originally social ones) is essentially different from object-oriented activity (mediated by tools of labour) and is not derivative from it. External (object-related) and internal (mental) activities are essentially different because of the different means of organisation and different types of mediation involved.

"These activities are so different from one another that the nature of the means employed in each case cannot be same." (Vygotsky, 1982,Vol.3, p.90)

My second thesis concerning the subject under discussion is that the view of cultural signs as psychological tools and as the organ of an individual was widely discussed in Russian non-Marxist philosophy at the beginning of the twentieth century. O. Mandelshtam (Russian poet and friend of Vygotsky), G. Shpet (pupil of Husserl), Viacheslav Ivanov (one of the fathers of Russian symbolism), P. Florensky, A. Losev and many others wrote extensively on this theme.

Thus, according to Pitirim Sorokin “...the sign environment forms different types of behaviour" (Sorokin, 1920, p.184-185). In claiming that the use of signs leads humans to a completely new and specific structure of behaviour and the creation of new forms of culturally based mental function, was Vygotsky closer to Marx than to non-Marxist P. Sorokin? At the same time, in claiming that the cultural sign is a means of social communication, was Vygotsky closer to P. Sorokin (who wrote that "connection of the individuals with the same symbols connects them to each other") than to Marx? (Ibid, p. 323).

In distinguishing between two types of signals in terms of natural and social (signs) was
Vygotsky closer to Marx than to G. Shpet? ${ }^{10}$. Finally, when speaking of the role of the word as a tool of mind was Vygotsky referring to the famous thesis of Marx or was he just repeating the position of P. Florensky who wrote that the word is amphibian, a mediator between inner and external realities (Florensky, 1990, p. 280) ${ }^{11}$ ?

\section{Some final remarks}

Discussing the problem of Marxist and nonMarxist aspects of the cultural-historical psychology of L. S. Vygotsky we should take into consideration at least two important circumstances.

1. It was not only Marxism which influenced Vygotsky. He was a child of the Silver Age of Russian culture and philosophy and the influence of this should not be underestimated. He tried to find answers to the questions concerning issues such as the individual and the world, personality and consciousness, mind and body, thought and speech, culture and nature, in other words, the same issues which had tormented contemporary Russian writers, poets and philosophers.

Consequently, some traits in Vygotsky's theory, traditionally considered Marxist - such as the concept of the social origins of mind or sign as psychological tool - also might have deeper and wider roots in the works of Shpet, Florensky, Blonsky, Sorokin and Meierhold. For political and ideological reasons Vygotsky was not able to even mention some of these names during Soviet times. Yet in his writings one can hear these 'voices of culture', often indirectly but unmistakably.

10 In his book of $1920, \mathrm{G}$. Shpet formulates in the following way: "There are two categories of symbols...natural and social" (Shpet, 1990, p. 428).

11 I could give more details on the connections of Vygotsky and the Russian philosophical tradition, but because of lack of space see Veresov, 2000. 
2. As for Marxism as such, it was not something like a "holy cow" for Vygotsky. During all three periods of his creative evolution Vygotsky had different approaches to what was true Marxist psychology and how it should be built. The final formula of his search could be found in his own words that the term 'Marxist psychology' "coincided with that of scientific psychology in general, wherever and by whomsoever it might be developed" (Vygotsky, 1982, p. 435). But by the 1930s Marxism was increasingly seen as a sort of 'scientific ideology'. Its leading principle was expressed not by the formula "true scientific psychology can be called Marxist psychology", but by "the Marxist psychology is the only scientific psychology." The theory of activity (in contradistinction to Vygotsky) identified itself as Marxist psychology. Any other theories (including Vygotsky's) were viewed as non-scientific and even anti-scientific.

In any case, when uncovering the problem of the relation between Marxism and Vygotsky we must take into account the dramatic and even tragic character of the relation. In saying that "Vygotsky was more than happy to call himself a Marxist." (Toulmin, 1978), we should also add that it was a mournful happiness.

\section{Literature}

Artamonov, V. I. (Ed.). (1994). L. S. Vygotskii i marxism v sovetskoi psihologii (diskussia) [L. S. Vygotsky and Marxism in Soviet psychology (discussion)]. Psyhologicheskii Journal, 15 (1), 115-126.

Asmolov, A. G. (1998). Vygotsky today: On the verge of non-classical psychology. New York: Nova Science.

Bakhurst, D. (1991). Consciousness and revolution in Soviet philosophy: From the
Bolsheviks to Evald Ilyenkov. Cambridge: Cambridge University Press.

Bruner, J. (1987). Prologue to the English Edition. In R. Rieber \&. A. Carton (Eds.). The collected works of L. S. Vygotsky. Volume 1. Problems of general psychology. London, Plenum, pp. 1-17.

Cole, M. \& Scribner, S. (1978). Introduction. In L. S. Vygotsky. Mind and society: The development of higher psychological processes. Cambridge: Harvard University Press, pp. 1-14.

Cole, M. (1995). Kulturnie mehanizmy razvitiya. Voprosy Psihologii, 3, 5-20.

Davydov, V. V. \& Radzikhovskii, L. A. (1985). Vygotsky's theory and the activity oriented approach in psychology. In J. Wertsch (Ed.), Culture, communication and cognition: Vygotskian perspectives. Cambridge: University Press, pp. 35-66.

Davydov, V. V. \& Zinchenko, V. P. (1989). Vygotsky's contribution to the development of psychology. Soviet Psychology, 27 (2), 22-36.

Davydov, V. V. (1996). Poniatie deyatelnosti kak osnovanie issledovanii nauchnoi shkoli Vygotskogo [Concept of activity as foundation of research in the scientific school of L.S. Vygotsky]. Voprosy psihologii, 5, 20-29

Elhammoumi, M. (2001). Lost - or merely domesticated? The boom in socio-historicocultural theory emphasises some concepts, overlooks others. In S. Chaiklin (Ed.), The theory and practice of cultural-historical psychology. Aarhus, Denmark, Aarhus University Press, 200-217.

Etkind, A. M. (1994). More on L. S. Vygotsky: forgotten texts and undiscovered contexts. Journal of Russian and East European Psychology, 32 (6), 22-36.

Florensky, P. (1990). Sochineniya [The works]. Moscow, Pravda.

Jensen, U. J. (1999). Categories on activity theory: Marx's philosophy just-in-time. In 
S. Chaiklin, M. Hedegaard, \& U.J. Jensen (eds.), Activity theory and social practice: Cultural-historical approach. Aarhus, Denmark: Aarhus University Press, 79-99.

Jones, P.E. (2000). The dialectics of the ideal and symbolic mediation. In V. Oittinen (Ed.), Evald Ilyenkov's philosophy revisited, Helsinki: Kikimora Publications, 205-227.

Jones, P.E. (2001). The ideal in cultural-historical activity theory: Issues and perspectives. In S. Chaiklin (Ed.), The theory and practice of cultural-historical psychology. Aarhus, Denmark, Aarhus University Press, 283-315

Kornilov, K. (1930). Psychology in the light of dialectical materialism. In C. Murchison (Ed.), Psychologies in the 1930s. Worcester, MA: Clark University Press.

Kozulin, A. (1996). The concept of activity in Soviet psychology: Vygotsky, his disciples and critics. In H. Daniels (Ed.), An introduction to Vygotsky. London: Routledge, pp. 264-274.

Lee, B. (1985). Intellectual origins of Vygotsky's semiotic analysis. In J. V. Wertsch (Ed.), Culture, communication and cognition: Vygotskian perspectives. Cambridge: University Press, pp. 66-93.

Lektorsky, V. A. (1999). Historical change of the notion of activity: Philosophical presuppositions. In S. Chaiklin, M. Hedegaard, \& U.J. Jensen (eds.), Activity theory and social practice: Cultural-historical approach. Aarhus, Denmark: Aarhus University Press, 100-113.

Leont'ev, A. A. (1996). Foreword. In Antologia gumannoi pedagogiki. Vygotskii [Anthology of human pedagogics]. Moscow: Shalva Amonashvili Publishing House, pp. 5-17.

Leont'ev, A. A. (2003). Foreword. In L. S. Vygotsky. Psihologiya razvitiya cheloveka [Psychology of development of man]. Moscow, Smysl.
Leont'ev, A. N. (1974-1975) The problem of activity in psychology. Soviet Psychology, 2 (13), 4- 33.

Leont'ev, A.N. (1977). Deyatelnost. Soznanie. Lichnost [Activity, consciousness and personality]. Moscow; Politizdat

Leont'ev, A. N. (1978). Activity, consciousness and personality. New York: Engelwood Cliffs.

Leont'ev, A. N. (1981). Problems of activity in psychology. In J. Wertsch (Ed.), The concept of activity in Soviet psychology. New-York, Sharp

Leont'ev, A. N. (1982). Predislovie. O tvorcheskom puti L. S. Vygotskogo [Foreword. On Vygotsky's creative evolution]. In L. S. Vygotsky, Sobranie sochinenii, Vol. 1, Moscow: Pedagogica.

Leont'ev, A. N. \& Luria, A. R. (1968). The psychological ideas of L. S. Vygotsky. In B. B. Wolman (Ed.). Historical roots of contemporary psychology. New York: Harper \& Row.

Maffiolo, D. (1993). From a social to a cultural approach to the study of cognitive activities: The fundamental role of semiotic systems. European Journal of Psychology of Education, 8 (4), 487-500.

Martsinkovskaya T. D.(1999) Problema esteticheskogo peresivaniya $\mathrm{v}$ kontseptsii psihologii sotsialnogo bytia G. G. Shpeta. [The problem of aesthetic experience in G. G. Shpet's concept of social being]. Voprosy psihologii, 6, 119-127

Meierhold, V (1920). Teatralnii slovar. [Dictionary of theatre]. Moscow. Gosizdat

Nardi, B. (Ed.). (1996). Context and consciousness: Activity theory and human-computer interaction. Cambridge: MIT Press.

Netchine-Grynberg, G. (1995). The functionality of cognition according to Cassirer, Meyerson, Vygotsky, and Wallon: Toward the roots of the concept of cognitive tool. In I. Lubek, R. van Hezewijk, G. Pheterson \& Ch. Tolman (Eds.), Trends and is- 
sues in theoretical psychology. New York: Springer Publishing, pp. 207-213.

Newman, F. \& Holzman, L. (1993). Lev Vygotsky: Revolutionary scientist. London: Routledge.

Radzikhovskii, L. A. (1979b). Osnovnie etapy nauchnoi raboty Vygotskogo. [Fundamental stages in Vygotsky's scientific work]. Doctoral (Kandidatskaya) Dissertation, Moscow: University Press.

Seve, L. (1999). Quelles contradictions? A propos de Piaget, Vygotki et Marx. In Y. Clot (ed.), Acec Vygotski. Paris: La Dispute, 221-240.

Shpet, G. (1989). Sochineniya [The Works]. Moscow

Shpet, G. (1990). Germenevtika i ee problemi [Hermeneutics and its probems]. Kontekst.

Sorokin, P. (1920). Sistema sotsiologii. [System of sociology] Vol. 1. Petrograd.

Tolman, C. W. (2001). The origins of activity as a category in the philosophies of Kant, Fichte, Hegel and Marx. In S. Chaiklin (Ed.), The theory and practice of culturalhistorical psychology. Aarhus, Denmark, Aarhus University Press, 84-92.

Toulmin, S. (1978). The Mozart in psychology. New York Review of Books, 28.

Tudge, J. (1999). Discovering Vygotsky: A historical and development approach. In N. Veresov. Undiscovered Vygotsky. Peter Lang

Tulviste, P. (1999). Activity as explanatory principle in cultural psychology. In S. Chaiklin, M. Hedegaard, \& U.J. Jensen (eds.), Activity theory and social practice: Cultural-historical approach. Aarhus, Denmark: Aarhus University Press, 66-78.

Van der Veer, R. \& Valsiner, J. (1991). Understanding Vygotsky: A quest for synthesis. Oxford: Blackwell.

Veresov, N. (2000). Vygotsky, Ilyenkov and Mamardashvili -Towards a monistic theory of mind (methodological notes). In
V. Oittinen (Ed.) Evald Ilyenkov's Philosophy Revisited. Kikimora Publishers, p. 131-145

Vygodskaya, G. \& Lifanova, T (1996). Lev Semenovich Vygotskii: Zizn, tvorchestvo, shtrihi $k$ portretu. [Lev Semenovich Vygotsky: life, creativity, traits of portrait] Moscow, Academia.

Vygotsky, L. S. (1925) Soznanie kak problema psihologii povedenia. [Cosciousness as a problem in psychology of behaviour] In K. N. Kornilov (Ed.). Psihologia i Marksizm. Moscow-Leningrad: Gosizdat, pp. 175-198.

Vygotsky, L. S. (1926a). Metodika reflexologicheskogo i psihologicheskogo issledovaniya. [Methods of reflexological and psychological investigation]. In $\mathrm{K}$. N. Kornilov (Ed.). Problemy sovremennoi psihologii. Leningrad: Gozisdat, pp. 26-46.

Vygotsky, L. S. (1926b). Pedagogicheskaya psihologiya. [Pedagogical psychology]. Moscow: Rabotnik Prosvescheniya.

Vygotsky, L. S. (1930). O sviazi mezdu trudovoi deyatelnostiu i intellektualnim razvitiem rebenka [On connection between labour activity and intellectual development in child]. Pedologia, 5/6, 588-596

Vygotsky, L. S. (1960). Razvitie vyschih psihicheskih funktsii [Development of higher mental functions]. Moscow; APN

Vygotsky, L. S. (1966/1933). Igra i ee rol v psihicheskom razvitii rebenka [Play and its role in the mental development of the child]. Voprosy psihologii [Questions in psychology], 6, pp. 62-76. (In Russian). Translated as Vygotsky, L. S. (1967). Play and its role in the mental development of the child. Soviet. Psychology. N.Y, V. 3. and The role of play in development. In: Vygotsky, L. S. (1978) Mind in society, Harvard University Press, p. 92-104

Vygotsky, L. S. (1976). O sviazi mezdu trudovoi deyatelnostiu i intellektualnim raz- 
vitiem rebenka [On connection between labour activity and intellectual development in child]. Defektologia, 6, 3-8.

Vygotsky, L. S. (1977). The development of higher psychological functions. Soviet Psychology, 3 (15), 60-73.

Vygotsky, L. S. (1978). Mind in society: the development of higher psychological processes. Cambridge: Harvard University Press.

Vygotsky, L. S. (1979). Consciousness as a problem in the psychology of behaviour. Soviet Psychology, 4, 3-35.

Vygotsky, L. S. (1981). The genesis of higher mental functions. In J.W. Wertsch (Ed.). The concept of activity in Soviet psychology. New York, Sharp.

Vygotsky, L. S. (1982). Sobranie sochinenii [The collected works]. Moscow: Vol. 1.

Vygotsky, L. S. (1983). Sobranie sochinenii [The collected works]. Moscow, Pedagogica, Vol. 3.

Vygotsky, L. S. (1991). Pedagogicheskaya psihologia [Pedagogical psychology]. Moscow: Pedagogika.

Vygotsky, L. S. (1994). The methods of reflexological and psychological investigation. In R. Van der Veer \& J. Valsiner (Eds.), The Vygotsky reader. Oxford: Blackwell, p 27-45.

Vygotsky, L. S. (1997). Educational psychology. Boca Raton: St. Luice Press..

Vygotsky, L.S. (1998). Collected works. Vol. 5. New York: Plenum.

Vygotsky, L. S. (1999). Consciousness as a problem in the psychology of behaviour.
In: N. Veresov. Undiscovered Vygotsky. Peter Lang, p.251-281

Wertsch, J. V. (Ed.). (1981). The concept of activity in Soviet psychology. New York: Sharpe, Armonk.

Wertsch, J. V. (1983). The role of semiosis in L. S. Vygotsky's theory of human cognition. In B. Bain (Ed.). The sociogenesis of language and human conduct. New York: Plenum.

Wertsch, J. V. (1985a). Introduction. In J. Wertsch (Ed.). Culture, communication and cognition: Vygotskian perspectives. Cambridge: University Press, pp. 1-18.

Yaroshevsky, M. (1992). L. S. Vygotsky i Marksizm v sovetskoi psihlogii [Vygotsky and Marxism in Soviet psychology]. Psychologicheskii Journal, 13(5), 84-99.

Zinchenko, P. I. (1939). Problema neproizvolnogo zapominaniya. Nauchnie zapiski Kharkovskogo gosudarstvennogo pedagogicheskogo instituta instrannih yasikov. Vol. 1, p. 145-187. Translated as Zinchenko, P. I. (1983-1984). The problem of involuntary memory. Soviet psychology, 2, 55-111.

Zinchenko, V. P. (1995). Cultural-historical psychology and the psychological theory of activity: retrospect and prospect. In J. V. Wertsch, P. del Rio, \& A. Alwares, (Eds.), Sociocultural studies of mind. Cambridge: University Press, p. 37-55.

Zinchenko, V (2003). Mysl I slovo. Podhody L. S. Vygotskogo i G.G. Shpeta [Thought and word. Approaches of L. S. Vygotsky and G. G. Shpet] Psihologicheskaya nauka I obrazovanie, 4, p. 31-39) 